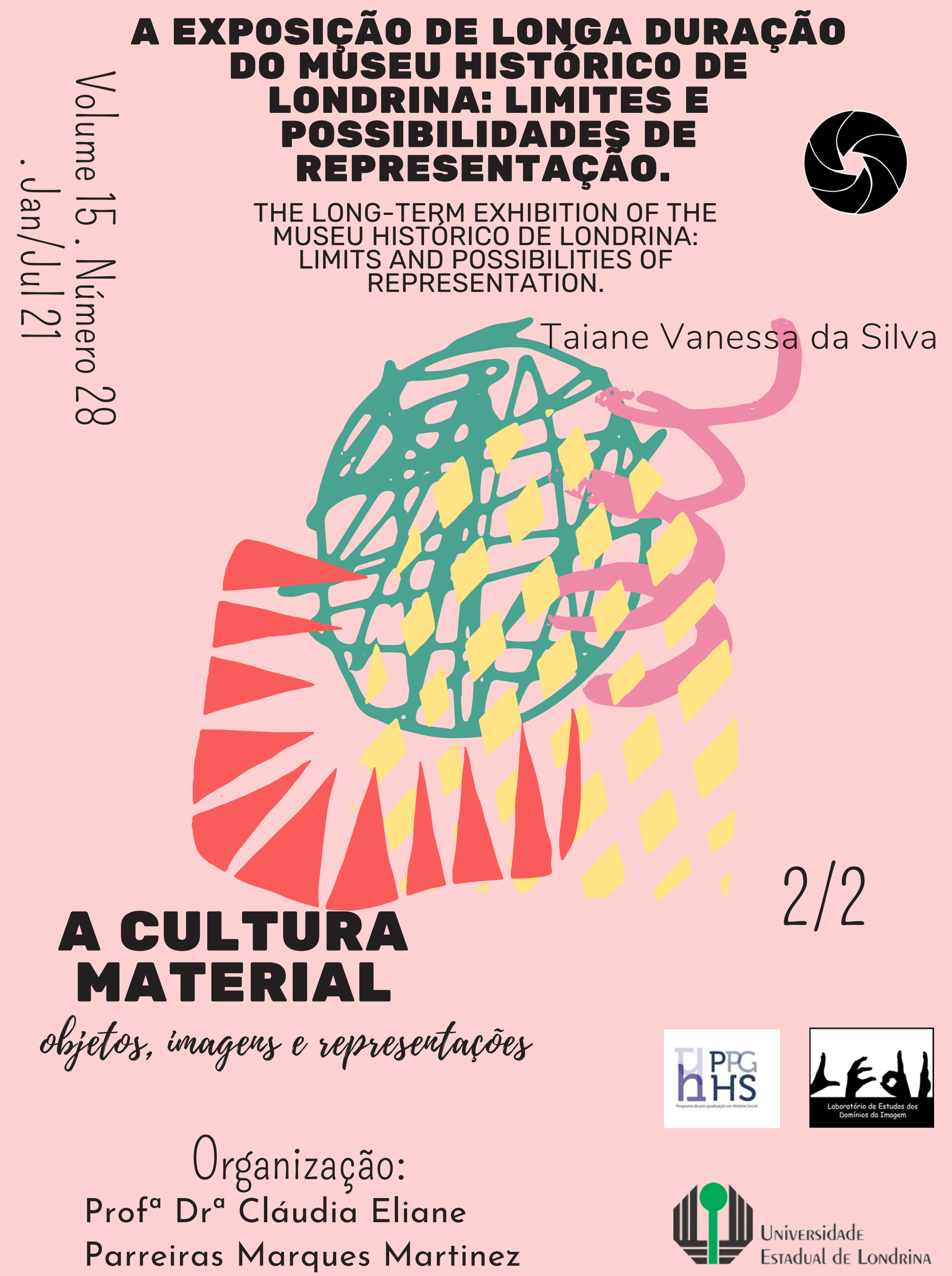




\section{A EXPOSIÇÃO DE LONGA DURAÇÃO DO MUSEU HISTÓRICO DE LON- DRINA: LIMITES E POSSIBILIDADES DE REPRESENTAÇÃO}

\section{HISTORICAL MUSEUM OF LONDRINA'S LONG-TERM EXPOSURE: THE POSSIBILITIES AND THE LIMITS OF THE REPRESENTATION}

Taiane Vanessa da Silva ${ }^{1}$
1 Doutoranda em Educação e mestre em História Social pela UEL, Londrina-PR, taaivanessa@hotmail. com. OCiD: https:// orcid.org/0000-00028183-9830.

Resumo: Busca-se com este artigo indicar os limites e possibilidades da exposição de longa duração do Museu Histórico de Londrina-PR (MHL) em relação às representações da história da cidade. A pesquisa tem como norte a análise textual qualitativa (MORAES, 2003) e o conceito de representação (CHARTIER, 1990). Selecionou-se como fonte histórica o memorial descritivo da exposição, a fim de compreender as intenções da sua produção, entre 1996 e 2000, e a narrativa construída no Museu Histórico. O documento selecionado indica o diálogo da exposição com a história "oficial" de Londrina, a qual destaca mitos fundadores e aspectos positivos da cidade em detrimento de memórias e identidades plurais. Porém, a partir de 2016, a exposição "permanente" do MHL passou a contar com intervenções e inclusões das memórias de povos indígenas, a fim de superar lacunas. Além disso, a pesquisa também aponta outras possibilidades de representações por meio de ações educativas.

Abstract: In this paper, we intend to indicate the limits and the possibilities of the Historical Museum of Londrina's long-term exposure concerning its relation with the city representations of Londrina, Paraná, Brazil. This research is based on qualitative textual analysis (MORAES, 2003) and the concept of representation (CHARTIER, 1990). We selected as historical source the exposure's descriptive memorial aiming to comprehend the intentions behind its production (1996-2000) and also the narrative that was built by the same museum. The selected sources indicate a dialogue between the exposition and the "Londrina's official history", which highlights founding myths and positivist aspects at the expense of other's memories and plural identities. However, since 2016 the long-term exposure suffered interventions from indigenous and their memories were used as a way to overcome historical gaps. Lastly, this research also points out other possibilities concerning representations through educational actions.

Palavras-chave: Museu Histórico de Londrina; Exposição museológica; Representação; Ação educativa

Keywords: Historical Museum of Londrina; Museum exposure; Representation; Educational actions 


\section{INTRODUÇÃO}

As instituições museológicas conservaram-se, durante um extenso tempo, como espaços sagrados, distantes da realidade social da população (JULIÃO, 2006a). Porém, a concepção contemporânea de museus, de acordo com a Lei no $11.904^{2}$, de 14 de janeiro de 2009 , os classificam enquanto

\section{[...] instituições sem fins lucrativos que conservam, investigam, comuni- cam, interpretam e expõem, para fins de preservação, estudo, pesquisa, edu- cação, contemplação e turismo, conjuntos e coleções de valor histórico, ar- tístico, científico, técnico ou de qualquer outra natureza cultural, abertas ao público, a serviço da sociedade e de seu desenvolvimento (BRASIL, 2009).}

Ao tomar os museus enquanto instituições a serviço da sociedade e de seu desenvolvimento, torna-se importante identificar qual a natureza do conhecimento disseminado em suas exposições. Assim, este artigo propõe a análise da exposição de longa duração ${ }^{3}$ do Museu Histórico de Londrina $(\mathrm{MHL})^{4}$ e de sua relação com a história "oficial" da cidade, considerando, também, as mudanças de narrativas ocorridas nos últimos anos e as possibilidades educativas daquela instituição.

Entende-se como história "oficial" os estudos históricos consagrados, que disseminaram em larga escala um "discurso de felicidade" entre as décadas de 1930 e 1970, sobre o processo de (re)ocupação do território londrinense. Esses estudos tinham como particularidade a "exaltação" de Londrina ou do norte do Paraná, como um "paraíso prometido”, colonizado de forma pacífica e próspera (ADUM, 2013).

A análise da exposição se pauta nas intencionalidades da produção e na formação de sua narrativa entre os anos de 1996 e 2000, por meio do memorial descritivo (BRUNO, 1998), o qual encontra-se disposto em quatro páginas, no acervo institucional do MHL referente às correspondências, no formato físico e digital. A pesquisa também considera as transformações ocorridas na exposição de longa duração do MHL, a partir de 2016, por meio de intervenções e inclusões de memórias de povos indígenas do norte do Paraná.

A investigação do memorial descritivo da exposição parte da análise textual discursiva de Moraes (2003). O autor propõe a desmontagem dos textos - conjunto de documentos -, denominada unitarização, na qual os materiais são analisados de forma detalhada e, portanto, fragmentados com o intuito de atingir as unidades constituintes dos fenômenos estudados.

\section{CONSIDERAÇÕES ACERCA DA HISTÓRIA “OFICIAL” DE LONDRINA}

No que diz respeito à história e à memória coletiva ${ }^{5}$ de Londrina, estas possuem versões consideradas "oficiais", as quais são rememoradas em eventos, escritos histó-
2 A definição de museu está em processo de redefinição, tendo em vista concepções cada vez mais democráticas, inclusivas e polifônicas. Entre 2016 e 2019, o Conselho Internacional de Museus (ICOM) promoveu encontros e oficinas a fim de estimular e colher propostas para uma nova definição. A redação da proposta está em andamento, com previsão de término para 2022.

${ }^{3}$ Aberta ao público no ano 2000.

${ }^{4} \mathrm{Em} 1970$ foi inaugurado, em Londrina, o Museu Geográfico e Histórico do Norte do Paraná. Na mesma década, no ano de 1978, recebeu o nome de Museu Histórico de Londrina "Pe. Carlos Weiss". Em 1986, o MHL foi transferido para as dependências da antiga estação ferroviária da cidade. Entre os anos de 1996 e 2000 , por meio do projeto "Memória Viva", o Museu foi revitalizado e reestruturado com alas expositivas e uma exposição de longa duração (HILDEBRANDO，2010) que permanece até os dias atuais com algumas modificações. 
ricos e lugares de memória. De acordo com Leme (2013), uma das questões exaltadas na história "oficial" da cidade está vinculada ao projeto colonizador desenvolvido pela Companhia de Terras Norte do Paraná (CTNP). A partir de 1919, a produção da monocultura cafeeira passou a ocupar o norte do Paraná, sendo interrompida pela eclosão da Primeira Guerra Mundial, geradora de uma crise econômica que afetou os fazendeiros. A solução encontrada pelo governo, para dar continuidade à ocupação do norte paranaense, pautou-se na concessão de terras a baixo custo para companhias colonizadoras financiadas pelo capital privado (LEME, 2012; ARIAS NETO, 2008).

No contexto apresentado, a CTNP, a qual era subsidiária da Paraná Plantations Syndicate, com sede em Londres e financiada pelo capital inglês, se destacou. A criação da companhia colonizadora é posterior a

\footnotetext{
[...] vinda da chamada Missão Montagu ao Brasil, no ano de 1923. Essa missão contemplava interesses do governo brasileiro em atrair investimentos e novos capitais estrangeiros para o país [...] A CTNP adquiriu, entre os anos de 1925 e 1927, do governo estadual paranaense, 515.000 alqueires de terras, nas quais planejava investir na plantação de algodão. Visava com isso complementar e, até mesmo substituir, a produção desse produto já existente em colônias inglesas na África [...]. Com a oscilação do mercado exportador do algodão no mercado internacional, a CTNP mudou de planos e transformou a região, naquela que seria uma das maiores produtoras de algodão do mundo, em um grande projeto imobiliário (LEME, 2013, p. 75).
}

A CTNP passou a investir em seu propósito imobiliário por meio de propagandas, retratando Londrina como a "terra prometida", para atrair compradores de diversas partes do Brasil e do mundo. É importando observar que a Companhia foi responsável pela (re)ocupação de várias outras cidades do norte do Paraná, mas instalou sua sede em Londrina, fator que justificou o "rápido crescimento populacional e econômico" (LEME, 2013, p. 77) da cidade. Entretanto, Leme traz à tona o outro lado do progresso, uma vez que a mesma Londrina idealizada pelas propagandas, em meio ao exaltado desenvolvimento econômico de uma cidade idealizada, contava com excluídos que incorporavam a periferia. Assim, percebe-se que o discurso "oficial" sobre a cidade de Londrina aborda apenas a atuação positiva da CTNP, silenciando os problemas sociais advindos do processo de "colonização".

Outra questão que incorpora a história "oficial” da cidade está relacionada, segundo Leme, com a figura do pioneiro - que chegaram entre 1929, data do início da (re) ocupação, e 1939 -, a qual consolida o mito fundador acerca da epopeia dos primeiros habitantes da cidade, vistos como aqueles que enfrentaram "as adversidades dos primeiros anos de colonização e que triunfou, social e economicamente” (LEME, 2013, p. 91).

No que diz respeito aos mitos fundadores, de acordo com Carlo Ginzburg, estes são usos políticos, uma vez que a "legitimação do poder remete necessariamente a uma história exemplar, a um princípio, a um mito fundador" (2001, p. 83). Sob este argumento
5 Entende-se a memória coletiva não apenas como um instrumento que reforça sentimentos de pertença a um grupo de passado comum (HALBWACHS, 1990), mas também como uma forma de dominação e objeto de luta pelo poder entre grupos sociais (POLLAK, 1992). 
podemos compreender a utilização política de uma versão da história da cidade de Londrina voltada para os aspectos positivos do início da (re)ocupação, a qual desconsidera, por exemplo, os conflitos e as memórias de outros grupos sociais.

Ressalta-se, também, o discurso mitificado sobre o "Eldorado" cafeeiro, iniciado em meados dos anos 1940, que coloca em cena, como protagonista, as plantações de cafezais. Essa representação legitima a existência de uma riqueza diferente no norte do Paraná, onde, de acordo com Arias Neto (2008), não havia as minas de ouro dos séculos XVII e XVIII, mas sim a oportunidade de transformar "através do trabalho, as riquezas naturais do norte e a fertilidade da terra, em ouro" (ARIAS NETO, 2008, p. 57). Assim, segundo o mesmo autor, os cafezais passaram a ser considerados o "ouro verde" da cidade nos anos de 1950.

É dentro desse contexto de progresso, entre os anos 1940 e 1950, que a figura do "pioneiro" ganha força. O discurso mitificado relacionado à atuação positiva da CTNP se estendeu e incorporou, passada a fase do início da colonização londrinense, a figura do pioneiro: aquele que veio por consequência da propaganda da terra de promissão dos anos de 1930, ou seja, a clientela de pequenos poupadores visada pela Companhia (BENATTE, 1996). Tal figura consolidou o mito fundador da epopeia dos primeiros colonizadores da cidade.

\section{A REPRESENTAÇÃO DA HISTÓRIA DE LONDRINA NA EXPOSIÇÃO DE LON- GA DURAÇÃO DO MHL (2000- 2015)}

Um dos objetivos da história cultural é "identificar o modo como em diferentes lugares e momentos uma realidade social é construída, pensada, dada a ler" (CHARTIER, 1990, p. 16). Logo, as apreensões da realidade são representações que buscam firmar concepções de mundo conforme as disposições dos grupos sociais (CHARTIER, 1990). Santos (2006) também problematiza as representações do passado como objetos de disputa. A autora parte do pressuposto de que o ato de interpretar não o mundo empírico, mas suas representações, não está relacionada a "criações arbitrárias" da realidade, mas a sistemas e conjuntos de representações capazes de oferecer um novo sentido envolvido por um jogo político e ideológico.

Sob essa perspectiva, os discursos da exposição de longa duração do Museu Histórico de Londrina serão analisado como representações do passado e da história dos londrinenses, construídas por grupos sociais que buscaram firmar suas concepções de mundo. Para compreender as representações presentes na exposição do MHL, entre os anos de 2000 e $2015^{6}$, propõe-se a análise do memorial descritivo daquela exposição de acordo com as propostas de Moraes (2003). Desse modo, o documento foi fragmentado
6 Essa temporalidade diz respeito ao período de vigência da exposição de longa duração, antes das mudanças ocorridas a partir de 2016, as quais serão abordadas ao longo do texto. 
em unidades de sentidos. Tais fragmentos serão relacionados a fim de perceber os reflexos do discurso "oficial” da história de Londrina na exposição, dentro da temporalidade proposta.

No que diz respeito à autoria do documento, este foi escrito pela museóloga, historiadora e docente Maria Cristina Bruno, contratada durante o período da revitalização daquela instituição (1996-2000), sob o financiamento do projeto Memória Viva. O contexto está ligado à segunda gestão de Conceição Geraldo, a qual também era docente do Departamento de História da UEL e dirigiu o museu entre 1976 e 1979, voltando em 1994 a 2002. Durante a segunda gestão, ela efetivou, em 1995, a constituição da Associação dos Amigos do Museu (ASAM), formada por "pessoas da cidade, cujas famílias, em sua maioria, tinham em comum, além de pertencerem a setores das chamadas elites locais, o fato de terem chegado nos primeiros tempos da história da cidade” (LEME, 2013, p. 146). De acordo com Leme, a ASAM, o Colégio Máxi - instituição escolar particular de Londrina -, entre outras instituições e empresas, colaboraram financeiramente com a revitalização do MHL.

Ao tomar conhecimento do contexto da produção e de seus autores, podemos partir para a análise do memorial descritivo da proposta museológica da exposição de longa de duração do Museu. Para o desenvolvimento da análise textual qualitativa, o documento foi fragmentado em duas unidades. A primeira aborda uma síntese do conceito, das temáticas da exposição e dos códigos museográficos ${ }^{7}$. Já a segunda unidade traz descrições de cada módulo, cenários, tablados, vitrines e painéis. É válido ressaltar que a exposição conta com quatro ambientes. O primeiro é a antessala, onde se encontra o prefácio, seguida de três salas maiores, as quais recebem os módulos temáticos da exposição.

Portanto, a primeira unidade de sentido possibilita uma visão do todo por meio da apresentação do conceito que embasa o discurso da exposição, a descrição inicial dos módulos e a listagem dos códigos museográficos. A segunda unidade permite um aprofundamento da organização narrativa. Logo, tendo em vista a visão geral da exposição (primeira unidade) e a descrição mais detalhada de cada ambiente (segunda unidade), nos próximos parágrafos serão apresentados a organização da exposição, o contexto de produção e discussões de autores que se debruçaram sobre o mesmo assunto.

A primeira unidade "pretende apresentar as estruturas fundadoras da historicidade da cidade de Londrina, a partir do conceito sobre o trabalho” (BRUNO, 1998, p. 1), o qual será entendido através dos seguintes vetores: organização coletiva da sociedade, aplicação de técnicas e tecnologias nos meios de trabalho, geração de indicadores econômicos, divisão entre o cotidiano público e privado, motivos de integração e desagregação social e a configuração de rupturas e mudanças.
7 Segundo Bruno (1998), os códigos museográficos da exposição são separados em três categorias: a primeira categoria é chamada de informações básicas, composta por cenários, vitrines, painéis ilustrativos e tablados; a segunda são informações argumentativas, com textos gerais e textos-legenda; por último, a terceira categoria é formada por informações complementares, com etiquetas nominativas, mapas e gráficos. 
De acordo com o documento, o prefácio da exposição tinha o intuito de abordar "esclarecimentos gerais sobre a ocupação do território, correspondente a cidade de Londrina, anterior ao século XX e ao empreendimento colonizador" (BRUNO, 1998). Segundo Leme (2013), o prefácio trazia textos que apresentam a grandiosidade populacional e econômica de Londrina, mencionando a importância dos pioneiros neste processo. A mesma sala também apresenta painéis com fotografias dos primeiros colonizadores derrubando a mata para o início da construção da cidade. Outra composição da antessala é uma vitrine com vestígios arqueológicos pré-coloniais pertencentes aos povos indígenas.

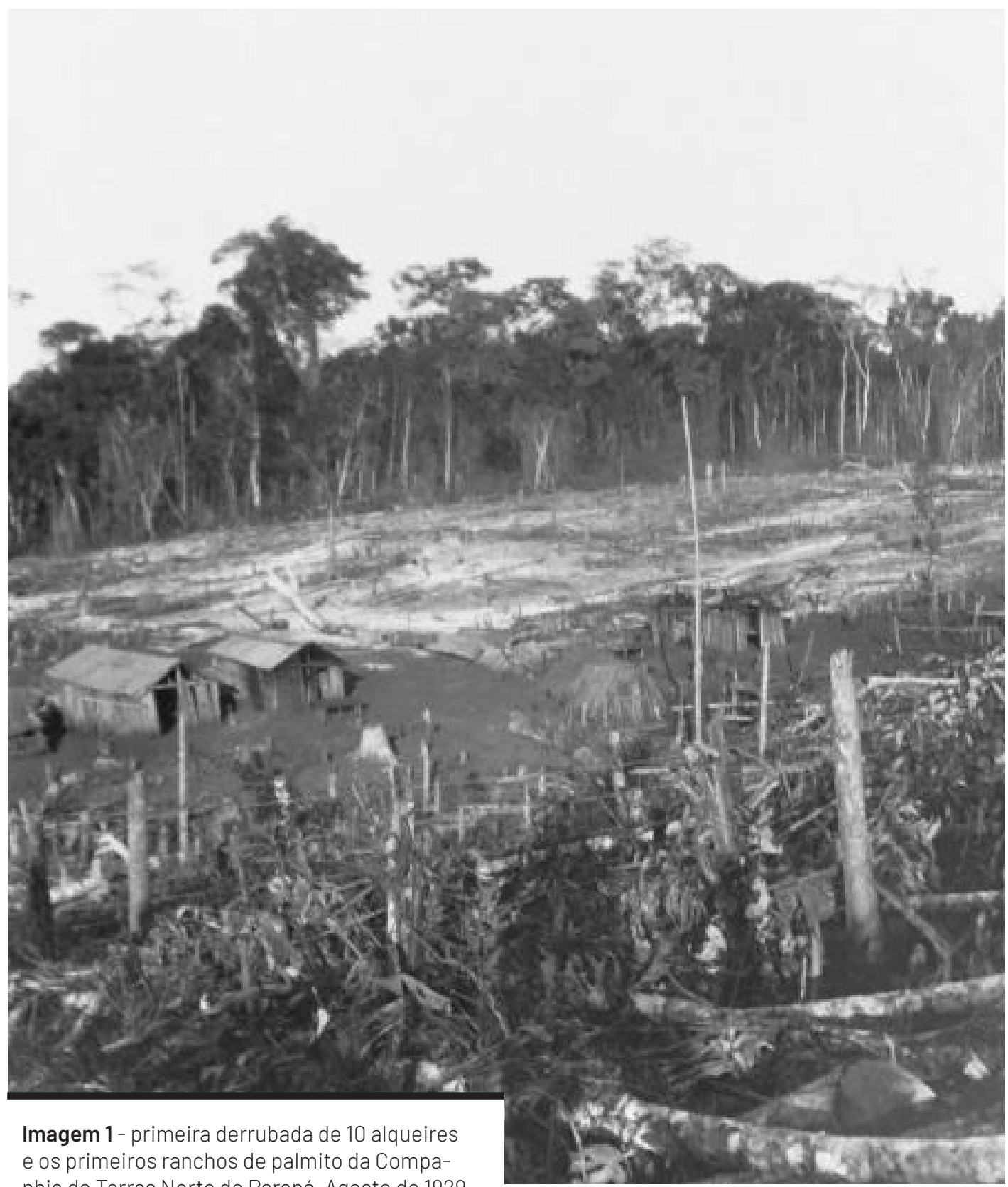

nhia de Terras Norte do Paraná. Agosto de 1929

Autor: George Craig Smith. Fonte: acervo Museu

Histórico de Londrina. 
A imagem 1, e outras que apresentam significados semelhantes, compõe um dos painéis do prefácio. Em diálogo com os objetivos da sala em questão, antes das reformulações de 2016, está imagem reforçava a história "oficial" da cidade, embasada no processo bem-sucedido da colonização, no trabalho dos pioneiros proeminentes e, especialmente, no progresso da civilização sobre a natureza. Além disso, as possíveis intencionalidades da produção da fotografia podem estar relacionadas ao discurso de progresso, uma vez que Smith, o autor da imagem, era funcionário da CTNP e um dos líderes da primeira caravana colonizadora.

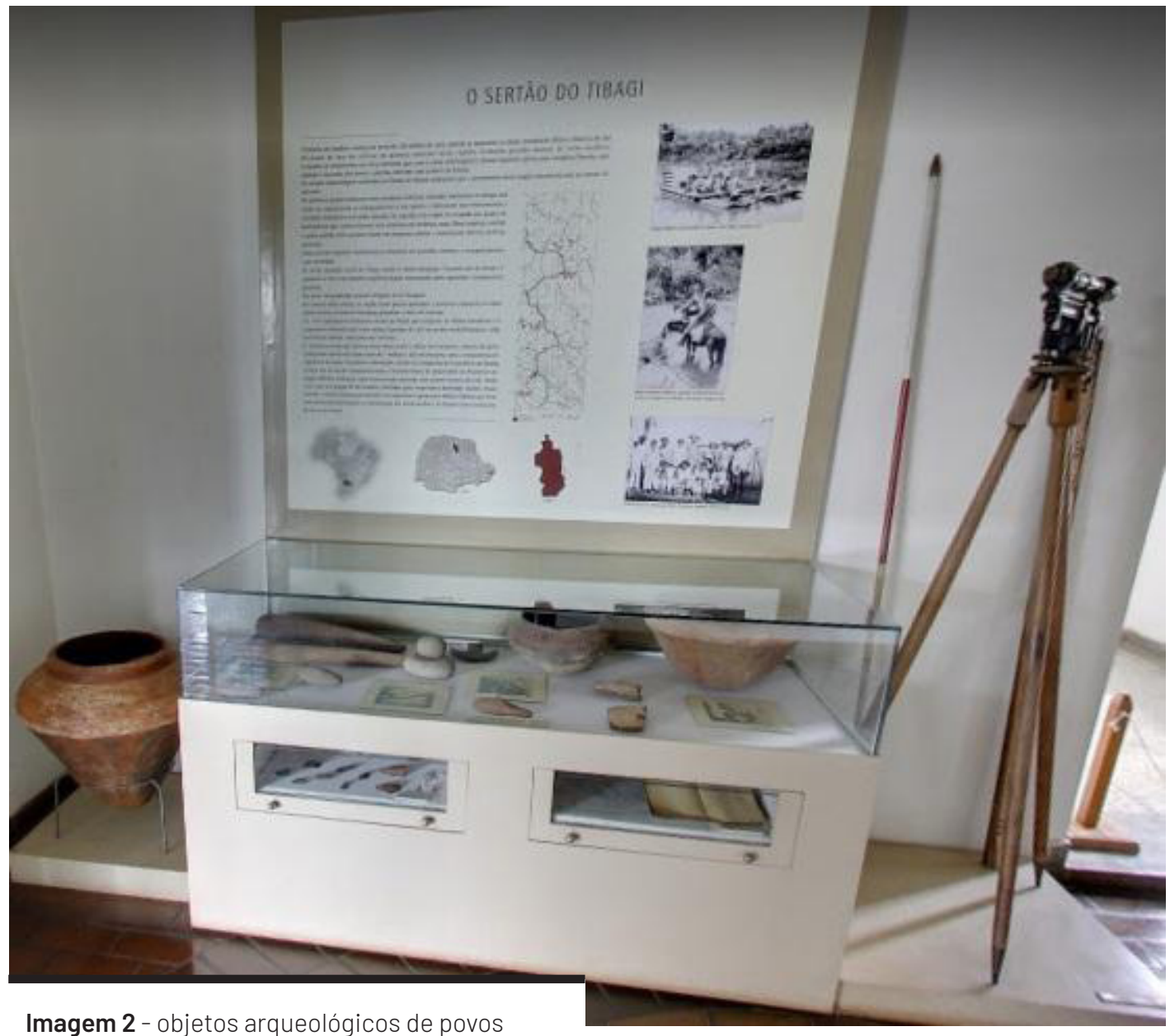
indígenas do norte do Paraná. Prefácio da exposição de longa duração do Museu Histórico de Londrina. 2015. Fonte: acervo pessoal.

Até 2015, o destaque à presença indígena na exposição de longa duração aparecia apenas no prefácio da Galeria Histórica por meio de vestígios arqueológicos, conforme pode ser visto na imagem 2, onde encontram-se objetos de pedra polida e de cerâmica. Esses objetos eram acompanhados de um painel com o texto intitulado O Sertão do Tibagi, o qual destacava a presença dos indígenas apenas em períodos pré-coloniais ou anteriores a chegada da CTNP8.
${ }^{8}$ De acordo com Martinez (2018), as primeiras coleções e acervo do Museu Histórico de Londrina foram adquiridas por Pe. Carlos Weiss, na década de 1970, o qual era diretor da instituição e professor de História Antiga e Medieval da antiga Faculdade de Filosofia e Ciências Humanas. Nessa primeira fase, priorizava-se os artefatos arqueológicos, objetos do cotidiano e do trabalho, além de outras culturas brasileiras, com destaque à nordestina. Entretanto, com a morte de Weiss, em 1976, o interesse pela etnografia, arqueologia e outras etnias, deixou de ser uma das prioridades do Museu, pois os gestores que atuaram na instituição, especialmente até o final do século $X X$, passaram a valorizar a figura do "pioneiro" nas exposições e na política de aquisição de acervos (MARTINEZ, 2018). 
Portanto, essa perspectiva apresentava diálogos com uma visão dicotômica, que permanece em muitos museus desde o século XIX. A exibição de coleções relacionadas à etnografia e à arqueologia geralmente são associadas aos elementos naturais e separadas dos acontecimentos de "grandes" personagens (JULIÃO, 2006a), especialmente aqueles de origem europeia.

O primeiro módulo, que sucede o prefácio, recebe o título $\mathrm{O}$ empreendimento colonizador, visando mostrar a apropriação e transformação do território. Este módulo conta com códigos museográficos que evocam a mata, a atuação da CTNP, a vida doméstica por meio de um rancho de palmito, fotografias e objetos, os primeiros comércios e serviços prestados à população, além dos primeiros meios de transportes, fotógrafos e cinegrafistas. Segundo Leme (2013), este módulo representa, em linhas gerais, a domesticação da natureza pelo homem e o desenvolvimento promissor de um pequeno povoado. Tais características são reforçadas por meio do cenário que representa o escritório da CTNP (imagem 3) e seus funcionários, que ocupa o maior espaço da sala em questão.

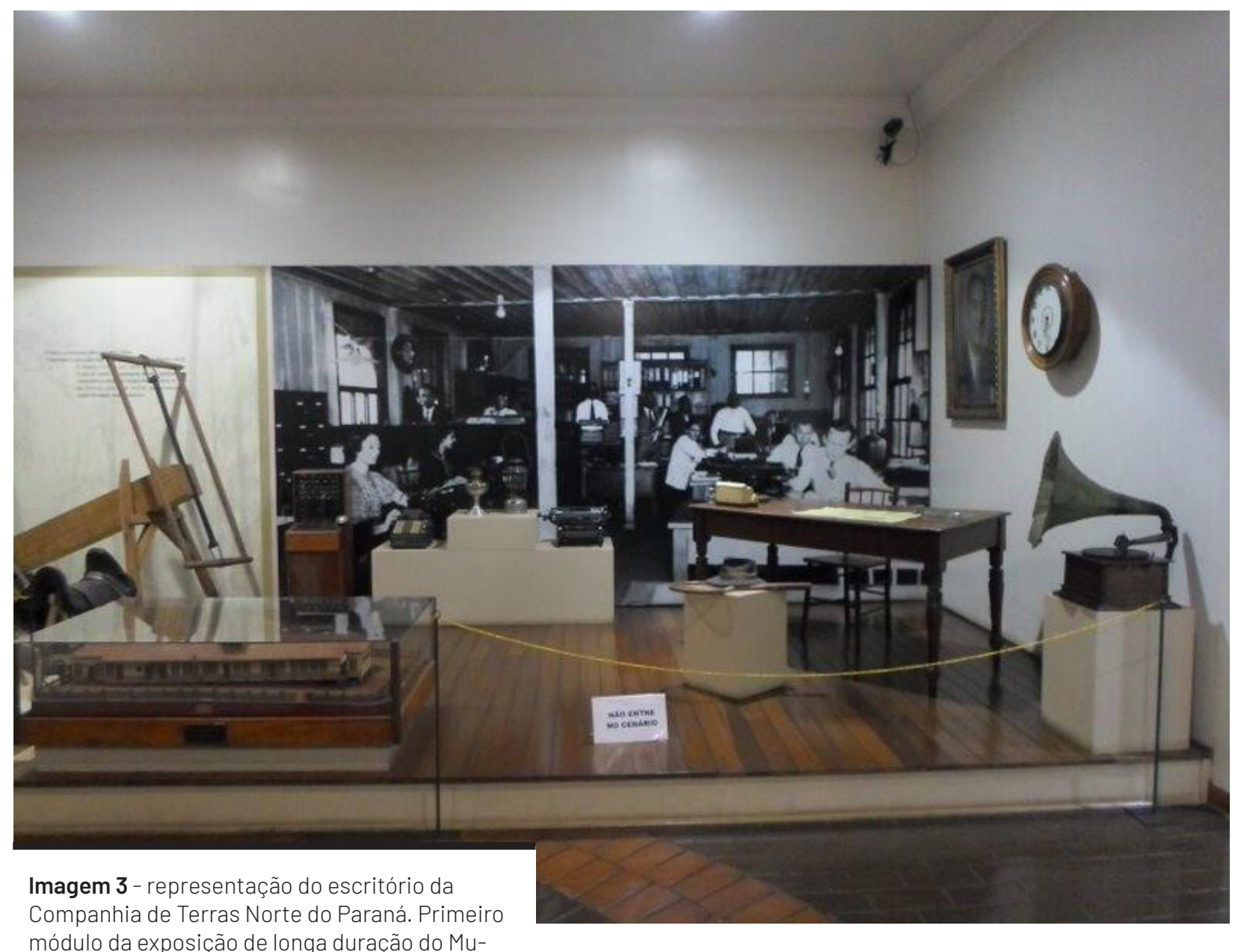
módulo da exposição de longa duração do Museu Histórico de Londrina. 2015. Fonte: acervo pessoal. 
O segundo módulo (imagem 4) recebe o nome de Emancipação de Londrina, tendo como base os movimentos migratórios e imigratórios - com ênfase nos imigrantes, uma vez que traz vitrines destinadas aos objetos destes habitantes - e a constituição da cidade. De acordo com o memorial descritivo, este módulo apresenta a contribuição dos diferentes seguimentos migratórios, a diversidade profissional, por meio de instrumentos de trabalhos voltados para a saúde, construção civil, farmácia, joalheria, imprensa, barbearia e alfaiataria e as questões político-administrativas relacionadas à emancipação da cidade em 1934.

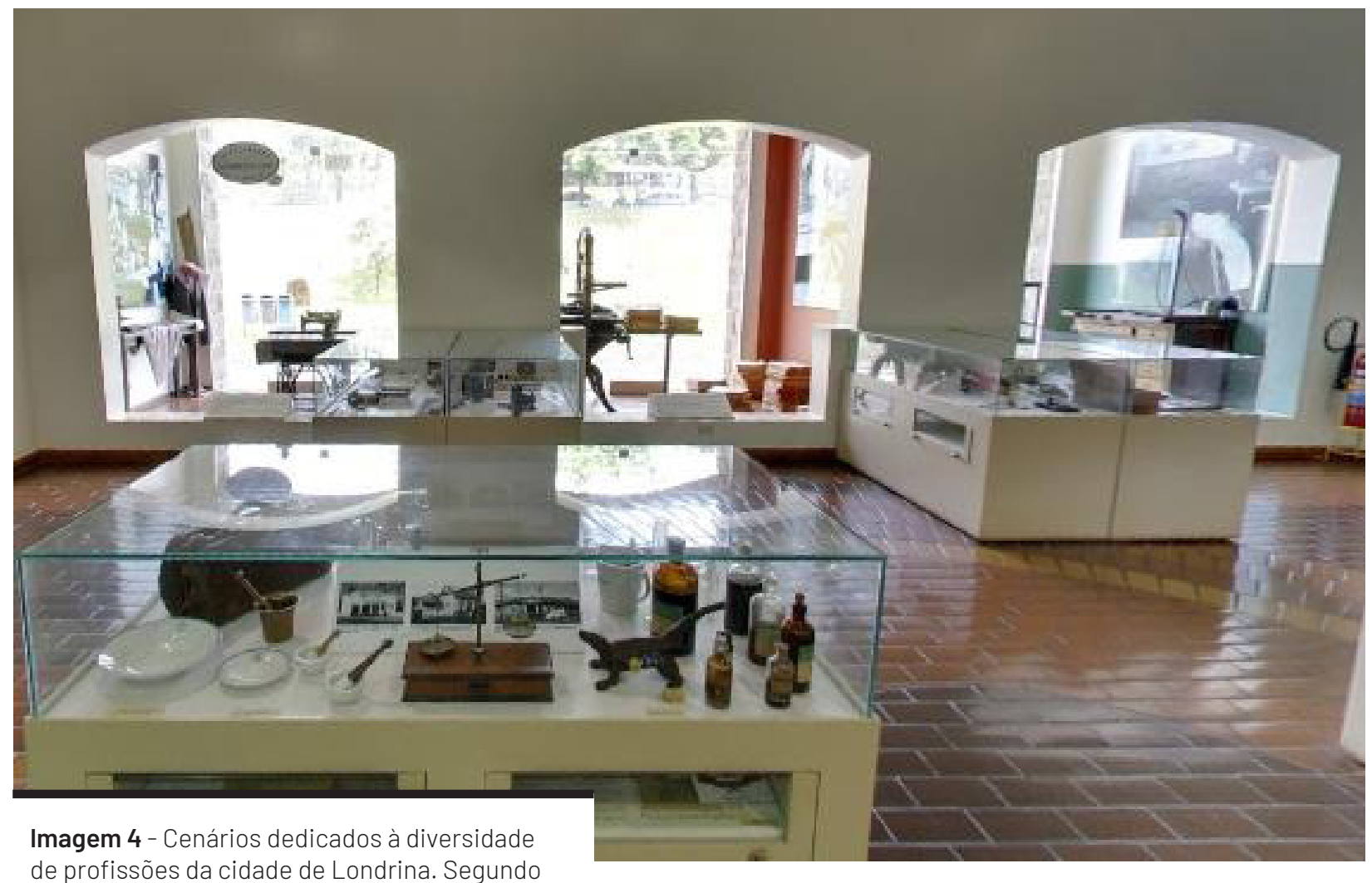
de profissões da cidade de Londrina. Segundo módulo da exposição de longa duração do Museu Histórico de Londrina. 2015. Fonte: acervo pessoal.

O terceiro módulo (imagem 5), intitulado A explosão econômica e o café, aborda temas relacionados à afirmação econômica da cidade e ao crescimento urbano. 


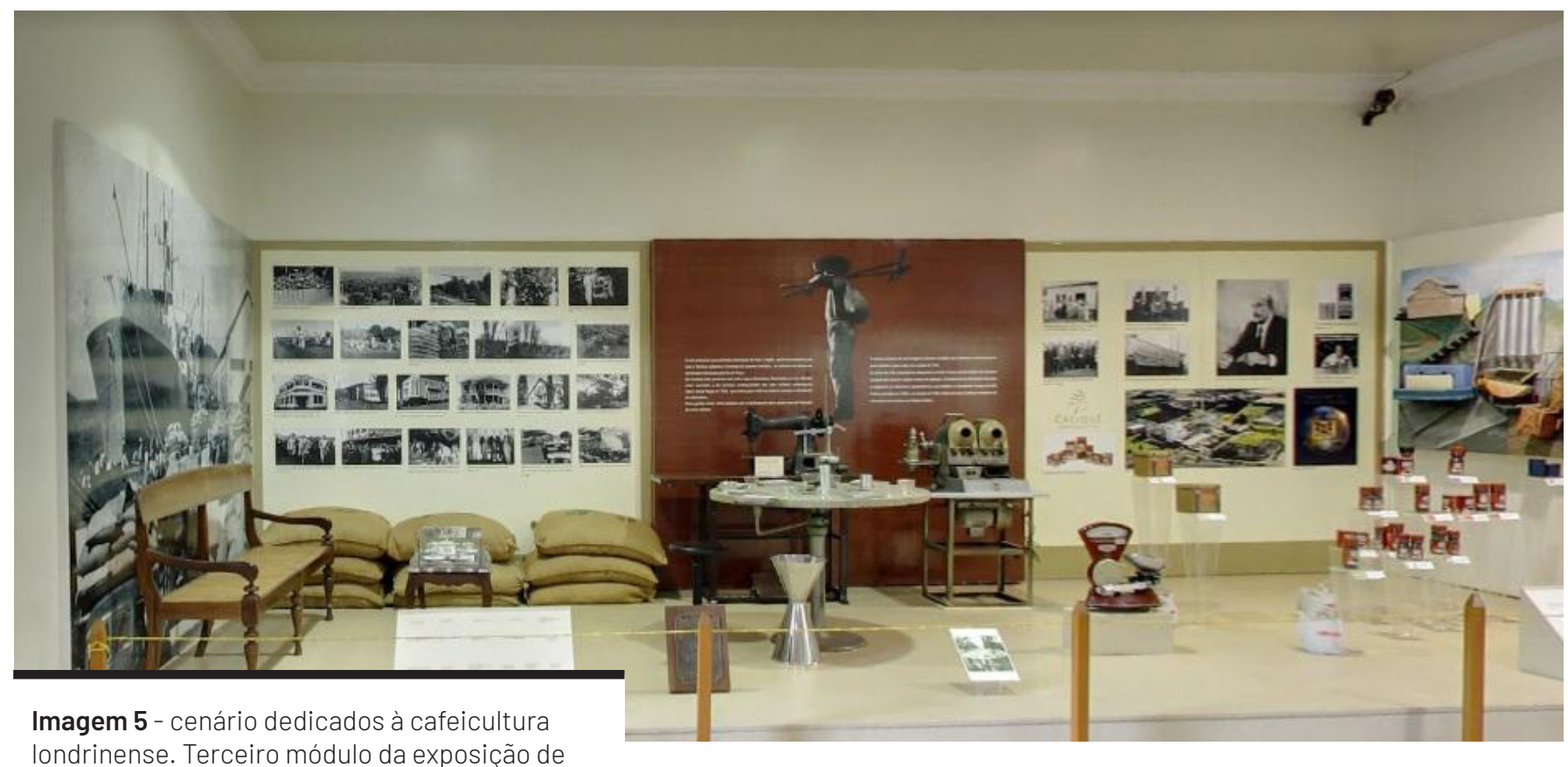

londrinense. Terceiro módulo da exposição de longa duração do Museu Histórico de Londrina.

2015. Fonte: acervo pessoal.

Os códigos museográficos visam evocar as mudanças econômicas em função da cafeicultura e seus desdobramentos nas instâncias públicas e privadas, a diversidade econômica, as mudanças e problemas da rápida explosão da economia, arquitetura, lazer, órgãos financeiros, sociedades coorporativas, empreendimentos comerciais e industriais, o crescimento econômico, aspectos da vida privada, manifestações públicas, o processo educacional (escolas, faculdades e universidades), meios de transporte, produção e exportação de café e a vida religiosa. Em linhas gerais, este módulo enfatiza

\section{[...] o rápido desenvolvimento e enriquecimento da cidade e região, fruto da economia cafeeira [...] a história da cafeicultura é celebrada como a respon- sável pela transformação da pequena vila "boca de sertão" na segunda maior cidade do Estado (LEME, 2013, p. 213).}

Os aspectos indicados possibilitam o estabelecimento de correlações entre duas tipologias de linguagens museológicas: museu-memória e museu-narrativa. No livro intitulado A escrita do passado em museus históricos, Santos (2006) escolheu o Museu Histórico Nacional e o Museu Imperial como objetos de análise, com o intuito de apreender linguagens distintas que possam ser contrastadas. Nos museus escolhidos, a autora buscou por duas características. A primeira se pauta no museu-memória, o qual, por meio dos objetos, visa uma alteridade em relação ao passado, ignorando a noção de tempo que se volta continuamente para o futuro, pois se baseia na autenticidade do objeto sobre o evento, gerando o culto da tradição ou de personagens históricos. Os objetos, portanto, não são exemplos de uma narrativa, eles são autênticos, visto que pertenceram àquela pessoa ou época. 
A segunda característica é o "museu-narrativa", no qual "o discurso histórico, racional e moderno substitui a história que se apoiava na memória" (SANTOS, 2006, p. 22) e passa a subordinar o objeto à linguagem das palavras. Posto isso, a autora aborda o MHN da década de 1980 como museu-narrativa. Nele existe um distanciamento entre passado e presente. O sentimento nostálgico, que revive a tradição e a identificação entre o ontem e o hoje, como é o caso do museu-memória, desaparece e é trocado pela razão, a qual prioriza um tempo linear e progressivo, onde a história não serve para rememorar fragmentos do passado, mas sim para a autocompreensão da humanidade. O MHN propõe, então, sintetizar a história da nação por meio de ciclos econômicos.

Sob os argumentos de Santos e as informações do memorial descritivo do MHL, percebe-se que a exposição de longa duração daquela instituição se aproxima das características de um museu-narrativa, ao passo que os objetos expostos estão subordinados a um discurso linear e progressivo, que tem como intuito sintetizar a história da cidade. Gilberto Hildebrando aponta para a mesma questão, pois a estrutura narrativa, presente no MHL, "pode ser percebida em contextos como a utilização massiva da cronologia" (HILDEBRANDO, 2010, p. 51),

Percebe-se que, assim como em museus-narrativa, a exposição promove uma síntese da história de Londrina, com uma cronologia que se inicia com a (re)ocupação do território, perpassa a chegada do empreendimento colonizador e a emancipação do município, e finda com a década de 1970, momento que marca a decadência cafeeira na região. Essa síntese enfatiza o progresso da cidade, uma vez que os colonizadores que chegam com a Companhia de Terras Norte do Paraná são lembrados por meio do viés da domesticação da natureza e do progresso do homem sobre a mata.

Apesar das características narrativas, o MHL também apresenta características de um museu-memória devido a alguns aspectos. O memorial descritivo da exposição traz, além da racionalidade do progresso e da síntese da história - características do museu-narrativa -, a ideia de sentimento nostálgico ao rememorar eventos do passado que geram identificações restritas. A narrativa da exposição permite o culto à tradição ao evocar a atuação positiva da CTNP e os feitos dos pioneiros. Nesse quesito, o Museu foge de uma das características do museu-narrativa, que é promover a autocompreensão da humanidade, no caso, dos habitantes de Londrina e região, apenas pela racionalidade, desconsiderando sentimentos nostálgicos e afetivos.

Tais aspectos da exposição anuncia uma relação com a história "oficial" da cidade. O empreendimento colonizador é tomado como protagonista e responsável pelo caminho progressivo da história de Londrina, de forma que os aspectos negativos da colonização são silenciados. Outro fator que manifesta esta relação com o discurso tradicional diz respeito ao progresso do homem sobre a natureza, abordando os pioneiros como 
sujeitos que superaram os problemas impostos pela mata. A narrativa, então, no que diz respeito ao prefácio e ao primeiro módulo, "acaba produzindo, de forma inevitável, uma sensação ao visitante de 'tempos difíceis”' (HILDEBRANDO, 2010, p. 51).

Além disso, outra característica que indica aproximações com o museu-memória é a existência de homenagens e objetos autênticos, que pertenceram a pessoas específicas. Por exemplo, no segundo módulo

[...] exibem-se homenagens pontuais a três pioneiros da cidade. No cenário da alfaiataria o Sr. Lupercio Luppi; no da imprensa o diretor da Folha de Londrina João Milanez e; no cenário da joalheria o senhor Ernesto Diez (LEME, 2013, p. 212).

Nesse sentido, percebe-se que a exposição do MHL apresenta uma coexistência de tipologias. Na Galeria Histórica é possível identificar tanto características de um museu-narrativa como as particularidades de um museu-memória. A análise das unidades do memorial descritivo, junto às discussões dos autores e imagens apresentadas, permite perceber a valorização de memórias e objetos de pessoas específicas. Ao mesmo tempo possibilitam narrativas onde os objetos são utilizados independentes de suas origens e autenticidade.

O diálogo com a linguagem narrativa, indicam que a tentativa da museóloga Cristina Bruno e dos funcionários do Museu Histórico de Londrina, que ajudaram a formular a proposta museológica, em trazer à superfície a história da cidade por meio do conceito de trabalho, foi "a oportunidade de propor uma mudança de paradigma conceitual para o MHL” (HILDEBRANDO, 2010, p. 50), pois a museologia tradicional nomeava o acervo como um valor em si mesmo (JULIÃO, 2006a). Portanto, no Museu

\footnotetext{
Manifestou-se o desejo de abandonar a tríade edifício-coleção-visitante, representativa da museologia tradicional, e sua substituição para uma nova configuração, cujo arcabouço teórico do movimento da nova museologia convencionou chamar de território-patrimônio-comunidade (HILDEBRANDO, 2010, p. 50).
}

Logo, o esforço dos atores citados em trazer uma narrativa embasada no conceito de trabalho indica um distanciamento em relação à museologia tradicional, pois possibilitou ao Museu romper com coleções pré-definidas. Assim, ao trabalhar com exposições compostas por coleções, os museus utilizam objetos que possuem relações definidas pelo criador da coleção, e, portanto, existe um voluntarismo "em que o sujeito elege objetos como parte reveladora de sua existência, seja por lazer, capricho, amuleto ou vaidade" (LOURENÇO, 1999, p. 13 apud JULIÃO, 2006b, p. 99). Ao optar pela característica da nova museologia formada pelo território-patrimônio-comunidade, o Museu passa a lidar com o acervo de objetos e documentos que permitem, de acordo com a mesma autora, compor novos conjuntos e sentidos, além de formular novas interações entre os objetos, possibilitando que sejam subornados a narrativas. 
Em outras palavras, ao estabelecer como fio condutor da exposição o conceito de trabalho, o Museu afrouxa laços com coleções preestabelecidas, fato que permite a utilização de acervos que produzam novos sentidos. Entretanto, mesmo que Cristina Bruno tenha inovado com o conceito escolhido, de acordo com Leme, no memorial descritivo "ela não conseguiu romper com alguns elementos-chave da narrativa tradicional que o museu, desde sua criação, carregava" (2013, p. 207), questão que dialoga com o contexto do projeto da revitalização, em razão de "nenhum lugar de memória escapa aos seus arabescos fundadores" (NORA, 1993, p. 23).

Para um melhor entendimento acerca da narrativa da exposição, torna-se novamente necessária a comparação com a historiografia do Norte do Paraná. Conforme Adum (2013), os escritos históricos da década de 1990 inseriram novos sujeitos na produção historiográfica, caracterizada como História em migalhas, pois abandonaram a perspectiva globalizante e a vocação de síntese. Novos personagens entram em cena histórica substituindo o centro pelas margens. Contudo, o memorial descritivo da exposição não renega a síntese da história, ao mesmo tempo em que não menciona, de forma significativa, novos personagens.

Logo, o conceito de representação proposto por Chartier (1990) está relacionado à narrativa da exposição de longa duração do MHL, visto que grupos sociais, vinculados àquele espaço de memória, tendo a oportunidade de formularem um discurso por meio da exposição de longa duração, buscaram por uma representação da realidade social que legitimasse suas concepções e autoridade.

Além disso, percebe-se a existência de conflitos na formulação dessa representação. Trata-se de uma exposição elaborada por meio de iniciativas de pioneiros proeminentes e de instituições privadas, que priorizaram um discurso positivo acerca da história de Londrina. Ao mesmo tempo, a formulação da narrativa contou com a participação de uma profissional da museologia e da história, a qual, por conta de sua formação, teve contato com perspectivas sobre a inserção de novos sujeitos e temáticas nos discursos museológicos e historiográficos, haja vista a utilização do conceito de trabalho como fio condutor da exposição.

Portanto, percebe-se que as representações são formuladas em um campo de disputas. Ademais, no período em que a exposição foi elaborada, a museologia passava por intensas transformações, que não impossibilitaram permanências. Na primeira metade do século XX, a área museológica comprometia-se com o incentivo da coesão social e o culto do universo material da elite, tornando os museus lugares distantes da realidade ou representações de sujeitos históricos comuns. Porém, ao longo da segunda metade do século passado, as reflexões críticas ligadas ao campo museal despontaram como novos caminhos (DESVALLÉES et al., 2013). 
$\mathrm{Na}$ década de 1960, os movimentos internacionais e intelectuais formularam críticas à atuação elitista da preservação do patrimônio (JULIÃO, 2006a). Dentro desta perspectiva, os museus passaram a ser considerados como lugares privilegiados à educação e à libertação dos indivíduos (DESVALLÉES et al., 2013).

Entretanto, as intencionalidades e o discurso da exposição de longa duração do MHL, até o ano de 2015, apontavam permanências em relação a museologia da primeira metade do século XX. Tais representações não impedem, porém, outras possibilidades educativas, as quais serão apontadas no próximo tópico.

\section{OUTRAS POSSIBILIDADES EDUCATIVAS}

A ação educativa no museu

[...] visa promover a participação, reflexão crítica e transformação da realidade social integrada à apropriação de uma cultura museal [...], deve ser entendida como ação cultural, que consiste no processo de mediação, permitindo o homem aprender, em um sentido amplo, o bem cultural, em vistas ao desenvolvimento de uma consciência crítica e abrangente da realidade que o cerca. [...], a ação educativa em museus promove sempre benefício para a sociedade, determinando, em última instância, o papel social dos museus (BRASIL, 2006).

Assim, o papel social de um museu - seu diálogo com a sociedade - conta com serviços educativos embasados na participação do público, pois as comunidades possuem e produzem referências culturais. Logo, a educação patrimonial tem fundamental relevância, haja vista que, segundo Denise Grinspum (2001), abarca as formas de mediação que proporcionam ao público a oportunidade de interpretar bens culturais, incentivando a preservação e valorização destes.

Dessa maneira, o professor que leva seus alunos a uma instituição museal pode contar com o apoio educativo. A visita, então, deve ser mediada tendo em foco a ressignificação da relação emissor e ouvinte, promovendo experiências cheias de sentidos e a interação de ambas as partes, de forma que "o público será visto como ator ativo e não como consumidor passivo" (CURY, 1999, p. 25).

Acerca da interação citada, cabe aqui o conceito de dialogia, desenvolvido por Mikhail Bakhtin, o qual diz respeito às diversas maneiras como duas ou mais vozes entram em contato (1994 apud SIMAN, 2004). Partindo desse conceito, Lana Mara Siman acredita que a função dialógica possibilita a elaboração de novos significados ou a reafirmação de significados já compartilhados, "visto que o discurso é formado por "metade nossa e metade do outro"' (SIMAN, 2004, p. 88), formando, então, a matéria prima para a produção de um novo significado.

Siman também aborda a questão da memória coletiva e sua influência na expe- 
riência dos alunos e o quanto isso pode facilitar a aprendizagem, quando dialoga com os recém-aprendidos conhecimentos históricos, ou dificultar, quando rompem com os mesmos conhecimentos. Segundo a autora, desde a infância os alunos elaboram raciocínios ligados à História.

Muito mais cedo do que supomos, os alunos adquirem experiências, representações e modos de pensar, não só por intermédio da escola, mas [...] por meio da memória social e da sua coletividade ou por outros veículos difusores da memória social, tais como a mídia (SIMAN, 2004, p. 84).

De acordo com a autora, os alunos vivenciam os efeitos de visões estereotipadas sobre classes sociais, culturas e grupos, influenciadas por relações sociais ou até mesmo por visões historiográficas dominantes, dificultando assim a desconstrução ou reconstrução do conhecimento por parte do professor no espaço formal e ou não formal da aprendizagem.

No que diz respeito à visitação de museus, Bittencourt (2008) estabelece uma breve abordagem sobre as visitas "tradicionais", nas quais o acervo museológico assume o caráter ilustrativo daquilo que é ensinado nas aulas de História. Para a autora, esse método mantém os objetos inacessíveis e, consecutivamente, não oferece meios para que os alunos possam imaginar esse passado. O potencial de um trabalho com essas fontes de cultura material, transformadas em documentos, reside no respeito conferido a esses objetos enquanto "peças de museu" e permitem o despertar do imaginário que não se restringe à visão de um "passado ultrapassado", mas sim de um conhecimento de cunho historiográfico (BITTENCOURT, 2008). Para tanto, torna-se essencial à busca por maneiras de transformar esses objetos em fontes de conhecimento histórico.

Para a análise do objeto exposto no museu, no entanto, há de se tomar nota acerca de dois importantes critérios prévios: o estético e o científico. No que se refere ao critério estético, é nessa etapa que o aluno deve observar, apresentar suas impressões e também ser informado acerca dos motivos daquele objeto ser parte integrante de uma organização social. Já naquilo que tange ao critério científico, é nessa etapa que se estabelece a identificação e descrição do objeto, levando em conta o local onde foi encontrado, do que é feito, para que serve e, posteriormente, ser identificado em relação a outros objetos.

Passadas as etapas "arqueológicas", pressupõe-se que o aluno tenha alcançado conhecimento suficiente para que lhe seja possível situar aquele objeto dentro do campo econômico e tecnológico de sua época, levando em consideração também a situação sociocultural na qual se circunscreve. Nesse processo, o diálogo entre aluno e educador é essencial já que, segundo Bittencourt (2008), questionar, ouvir respostas e complementar informações exprime a relação fundamental para a descoberta e a interpretação de objetos. 
Para que a visita escolar a um museu histórico seja bem trabalhada, de acordo com Ramos (2004), ela deve começar em sala de aula com objetos do cotidiano que possibilitem reflexões sobre suas práticas e relações sociais. Essa questão pode ser relacionada às perspectivas de Meneses (2005), o qual afirma que o acervo de um museu é importante, pois estamos imersos em um oceano de coisas materiais que são necessárias para a nossa sobrevivência. Assim, os objetos participam da produção e reprodução social. Portanto, problematizar os objetos em sala de aula possibilitará à visita reflexões mais satisfatórias.

Ramos defende uma "História dos objetos" que implica no estudo da "História nos objetos", de forma que "o objeto é tratado como indício de traços culturais que serão interpretados no contexto da exposição do museu ou na sala de aula. Assim, qualquer objeto deve ser tratado como fonte de reflexão" (RAMOS, 2004, p. 22). Dessa forma, ao estudar a historicidade dos objetos, os alunos podem ser sensibilizados sobre as reflexões que um museu histórico pode oferecer, perdendo a ideia de que a exposição é o local onde se "visita o passado".

O autor propõe, então, que a preparação para a visita e a visita propriamente tenham como base os objetos geradores, os quais são objetos da cultura material que possuem profundos significados para os que vão ter a alfabetização museológica, e, consequentemente, devem ser objetos do cotidiano, para que as problemáticas possam partir do mundo vivido. As influências dessa proposta se pautam na pedagogia de Paulo Freire sobre as palavras geradoras, as quais devem ser palavras significativas para alunos em processo de alfabetização e matéria prima para desenvolver a escrita e a leitura das palavras a partir das leituras de mundo. O autor propõe que os objetos geradores possibilitem leituras novas do mundo (RAMOS, 2004).

Portanto, é fundamental utilizar objetos que partam do mundo vivido para depois iniciar as relações com objetos do passado, que não possuem mais valores de uso ou que tiveram suas formas transformadas - como uma televisão. Tal perspectiva possibilita a reflexão sobre a multiplicidade cultural que existe em um objeto e a "trama de valores e seres humanos que reside na criação, no uso, na transformação, na destruição e na reconstrução de objetos" (RAMOS, 2004, p. 34). As propostas de Ramos sob o uso de objetos geradores permitem que outras representações e narrativas sejam inseridas dentro de uma exposição museal.

No caso do Museu Histórico de Londrina, o rancho de palmito e a loja de secos e molhados que compõem parte do $2^{\circ}$ módulo são exemplos de cenários compostos por objetos simples do cotidiano que podem ser comparados aos objetos do presente vivido pelos alunos. Portanto, problematizar os objetos presentes naqueles cenários permite reflexões sobre as mudanças e permanências entre o cotidiano de diversos sujeitos históricos da época representada e o presente dos alunos de forma a não reproduzir passi- 
vamente a narrativa empregada na exposição.

O potencial educativo daquela exposição não deve ser abordado de forma unilateral. O MHL conta com objetos, documentos escritos e fotografias que podem e devem ser problematizados como fontes históricas, trazendo à tona outras narrativas e, até mesmo, uma reflexão crítica acerca do discurso defendido no circuito da exposição, uma vez que nas reformulações museológicas o papel dos museus foi redefinido "tendo como objetivo maior o público usuário, imprimindo-lhe uma função crítica e transformadora da sociedade" (JULIÃO, 2006a, p. 27).

Ao tomar o diálogo e a participação da comunidade como pontos de partida, o apoio da ação educativa do MHL, entendido como o papel social da instituição, é de fundamental importância, uma vez que os serviços educativos oferecidos por esse setor têm como um de seus intuitos instigar a reflexão crítica do visitante acerca do acervo por meio da mediação. De acordo com Ramos (2004), desenvolver políticas de atendimento aos estudantes é explorar a multiplicidade de papeis educativos do espaço museológico. Logo, a ação educativa do MHL promove, segundo Aryane Kovacs Fernandes (2014), atividades que envolvem estudantes da licenciatura em História da UEL e instituições escolares, além de materiais educativos e exposições itinerantes. De acordo com a autora,

Há oficinas de fotografia documental, mapas alternativos, entrevistas, contação de histórias, maquete e objetos tridimensionais. Estas propõem às instituições escolares a análise de diferenciados documentos históricos [...] A ação educativa também proporciona a exposição itinerante, a qual se configura como o empréstimo às escolas de parte do acervo das exposições temporárias. Ainda, elaboração de materiais educativos, como o jogo da memória trilíngue (português, Kaingang e Guarani). Estas atividades proporcionam interação com o conteúdo histórico, concepção de espaço, memória, patrimônio e preservação (FERNANDES, 2014, p. 17).

Outra função da ação educativa do MHL, destacada por Fernandes, diz respeito às visitas mediadas pelo espaço do Museu a grupos escolares visitantes, uma das partes fundamentais do papel social da instituição museal, visto que situa o visitante para a reflexão da exposição por meio de questionamentos que o leva a interpretação. Nesse sentido, a mediação se constrói por meio do diálogo entre o educador do museu e o público que visita aquele espaço, de forma a nutrir a interpretação dos objetos como finalidade, tornando-os fontes históricas que dizem acerca do homem no tempo.

Os objetos também podem ser tomados enquanto documento/monumento, os quais são, segundo Le Goff (1984), materiais da memória. Os monumentos, que estão simultaneamente relacionados ao poder e à perpetuação de lembranças para o futuro, podem evocar o passado, porque são heranças do mesmo. Já os documentos são selecionados pelos historiadores que os caracterizam enquanto provas. Porém, Le Goff alerta 
sobre a inexistência de documentos inócuos, de forma que todo documento deve ser considerado monumento, haja vista que é produto da sociedade, das relações de poder, de seleções e intencionalidades. Portanto, os documentos/monumentos são resultados do empenho das sociedades históricas para deixar às gerações futuras certa imagem de si própria.

Em face dos argumentos apresentados, os objetos analisados como documento/ monumento podem abordar a narrativa da exposição como fruto de intencionalidades de uma sociedade ou grupos específicos. Ao mesmo tempo, problematizar a exposição por meio de objetos geradores possibilita outras narrativas e representações. Por conseguinte, o MHL tem a oportunidade de promover a participação do visitante, superando a ideia em que o acervo possui um valor em si mesmo, independente e distante do público que o observa.

\section{AS INTERVENÇÕES E INCLUSÕES DE MEMÓRIAS DOS POVOS INDÍGENAS DO NORTE DO PARANÁ NA EXPOSIÇÃO DO MHL}

Ainda sobre outras possibilidades representativas dentro do MHL, destacam-se a exposição temporária e as intervenções e inclusões das memórias dos povos indígenas do norte do Paraná na exposição de longa duração. O estudo de Martinez (2018) soma à essa discussão, pois as fases que a autora percebeu existirem na trajetória do MHL contribuem para a percepção de mudanças de paradigmas nas gestões de Angelita Visalli (2008-2012) e Regina Alegro (2012-2019). Nesse estudo, Martinez separa o Museu em quatro fases que demonstram ações diferenciadas dentro daquela instituição, sendo a última relacionada às mudanças político-administrativas e de paradigmas.

Em 2013, o Museu histórico de Londrina produziu a exposição temporária Povos Indígenas no Norte do Paraná, em parceria com os Kaingang e Guarani das terras indígenas do Apucaraninha e de São Jerônimo-PR. Conforme a imagem 6, percebe-se que a narrativa expositiva rompeu com a dicotomia que abordava os povos indígenas apenas como personagens do período pré-colonial. A fotografia indica, por meio das imagens expostas na parede e da presença de indígenas da etnia Kaingang, a atuação desses povos na atualidade. Como desdobramento, o Museu produziu um catálogo educativo trilíngue e transformou parte da exposição em uma exposição itinerante, ambos destinados, em especial, às escolas de Londrina e região (SILVA, 2016). 


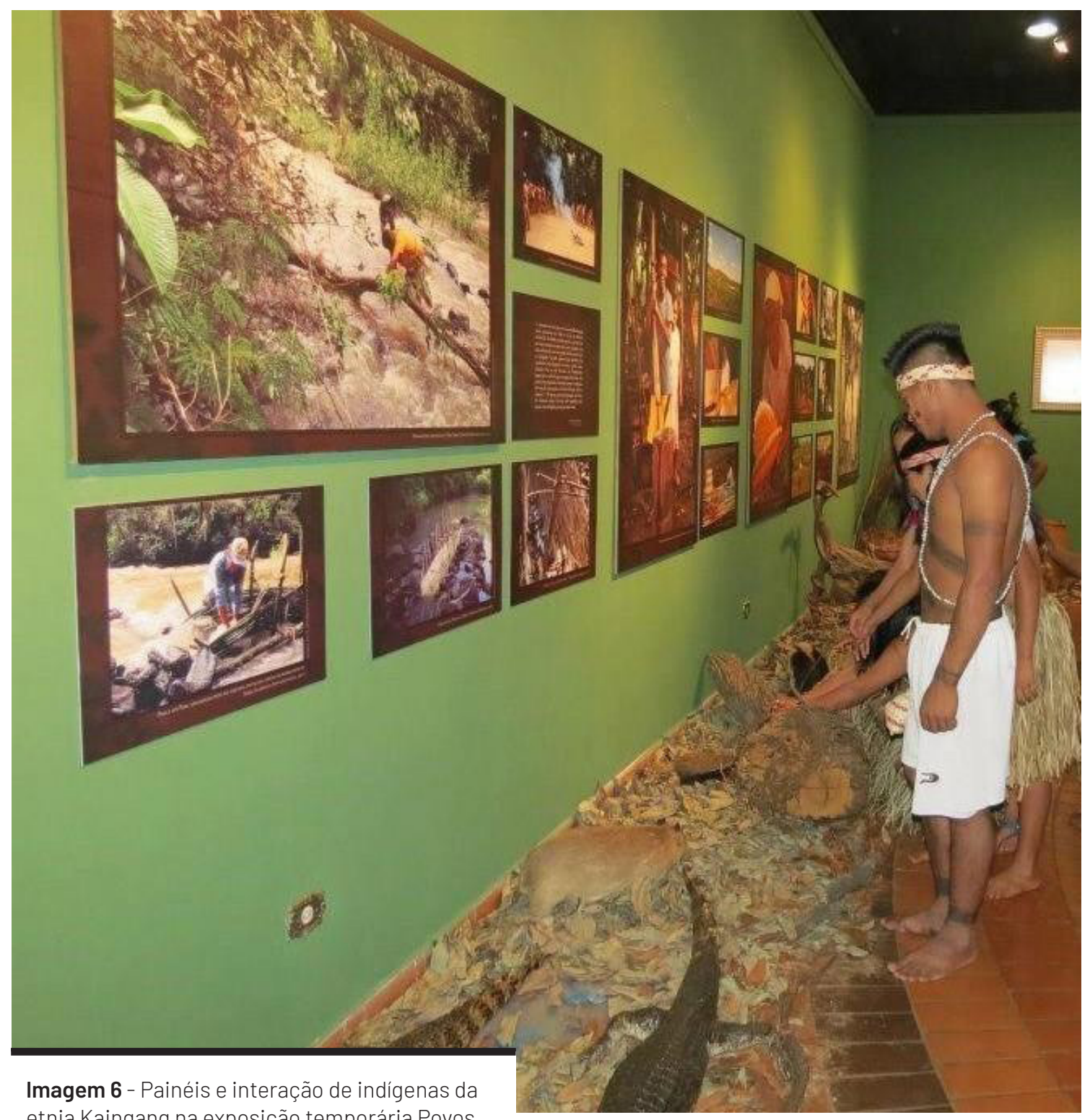

etnia Kaingang na exposição temporária Povos Indígenas no Norte do Paraná. Terceiro módulo da exposição. 2013. Fonte: Amauri Ramos.

Algum tempo depois, em 2016, pesquisadores vinculados ao MHL, junto aos povos indígenas de Londrina e região, promoveram o Seminário sobre Culturas Indígenas e Patrimônios Museológicos do Paraná para aprofundar "os conhecimentos sobre os acervos das culturas indígenas conservadas nos museus de Londrina e região" (SETI, 2016). Um dos resultados deste seminário foi a intervenção na antessala do Museu Histórico de Londrina, por meio de escritos feitos pelos povos indígenas da região, questionando o prefácio da exposição que citava a existência de um "vazio demográfico" antes do processo de (re)ocupação da CTNP.

Outro reflexo das discussões ocorridas nos últimos anos, é a exposição Inclusão da memória indígena na exposição permanente do Museu Histórico de Londrina que inse- 
riu, a partir de dezembro de 2019, referências dos povos indígenas na exposição de longa duração, a fim de amenizar as lacunas citadas no segundo tópico do presente texto.

Na imagem 7 é possível observar reformulações ocorridas no prefácio da exposição no que diz respeito à memória dos povos indígenas do norte do Paraná. Na imagem 8 percebe-se a inserção da cultura material e imaterial in dígena em outros módulos da exposição. Assim, nota-se uma tentativa de romper com concepções generalizantes acerca da atuação desses povos no passado e no presente, visto que os cenários, vitrines painéis passaram a valorizar a diversidade e a presença de indígenas no norte paranaense em temporalidades para além do período pré-colonial.

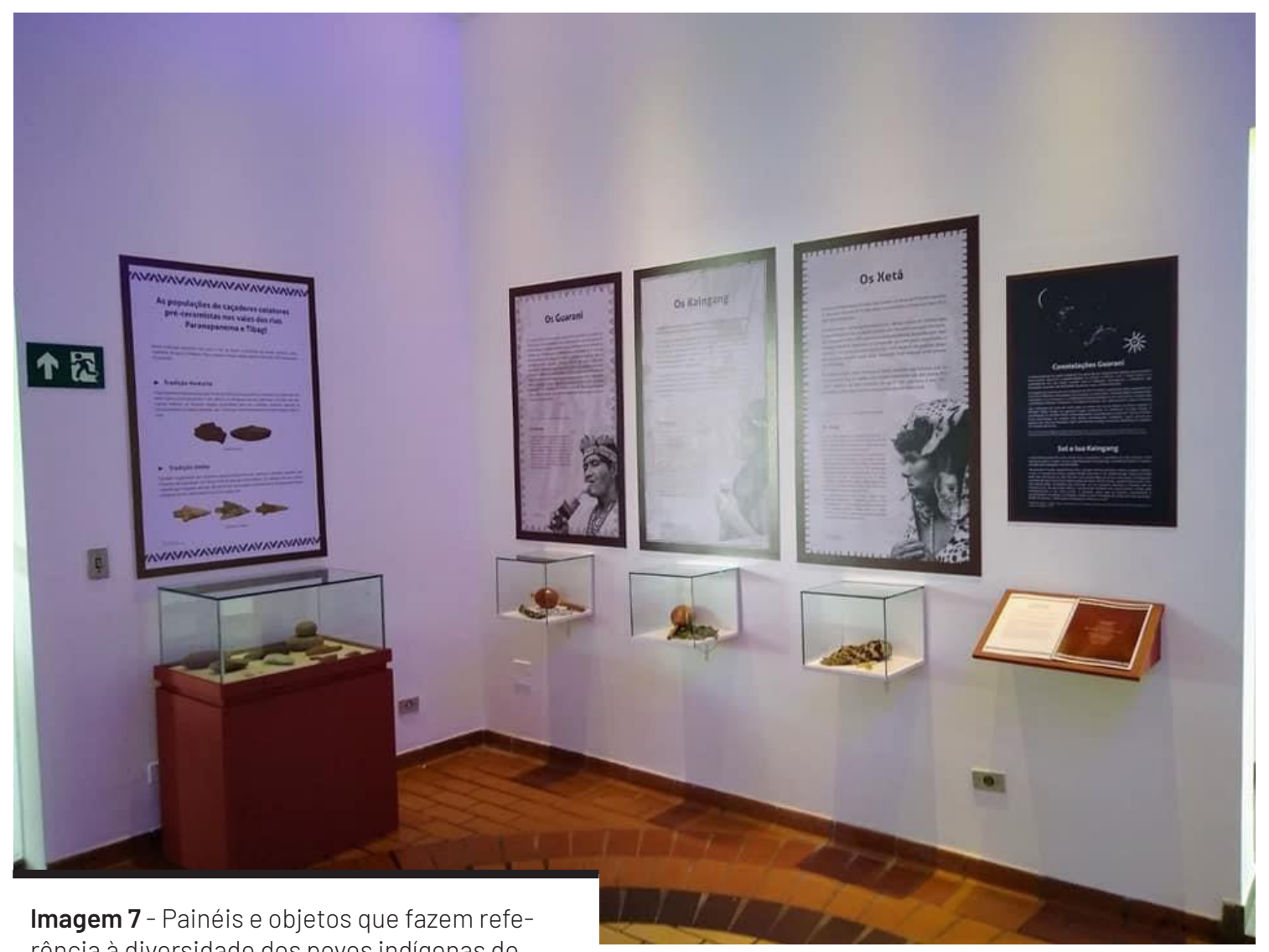

rência à diversidade dos povos indígenas do norte do Paraná. Prefácio da exposição de longa duração. 2019. Fonte: Amauri Ramos. 


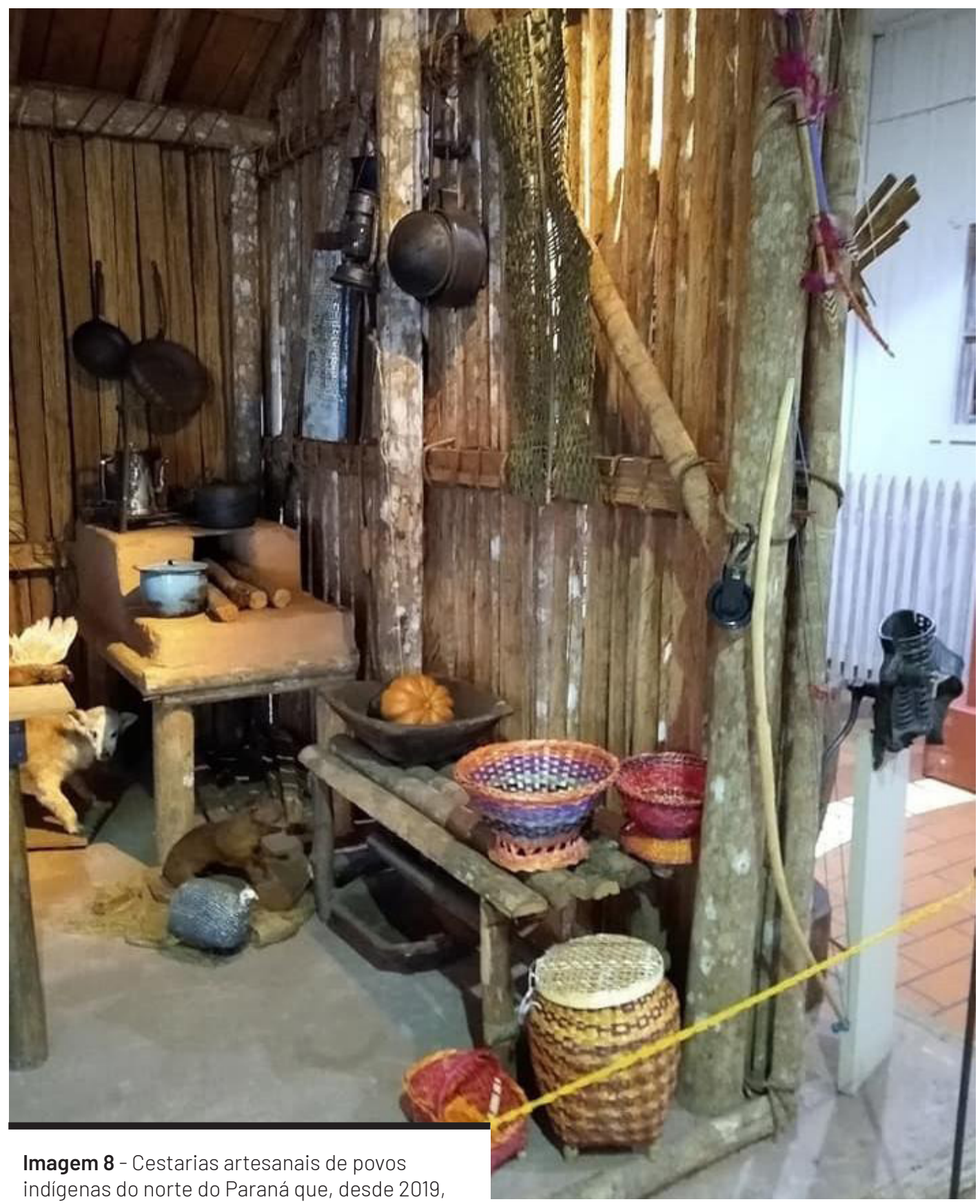
indígenas do norte do Paraná que, desde 2019 compõem o cenário do rancho de palmito junto a outros utensílios domésticos e artesanais.

Primeiro módulo da exposição de longa duração. 2019. Fonte: Amauri Ramos.

Percebe-se que as iniciativas da última década procuram pelo diálogo com os diferentes grupos sociais que participam da história de Londrina. Tais ações visam desconstruir os estereótipos e visões dicotômicas presentes na exposição de longa duração do MHL até o ano de 2015. Em outras palavras, os sujeitos responsáveis pela formulação de narrativas no Museu Histórico de Londrina, atualmente, buscam mediar representações do passado mais democráticas e polifônicas, em diálogo com as reformulações museológicas das últimas décadas. 


\section{REFERÊNCIAS}

ADUM, Sonia Maria Sperandio Lopes. Historiografia norte paranaense: alguns apontamentos. In: ALEGRO, Regina Celia; MOLINA, Ana Heloisa; CUNHA, Maria de Fátima; et al. (Org.). Temas e questões para o ensino de história do Paraná. Londrina: Eduel, 2013, p. 01-26.

ARIAS NETO, José Miguel. O Eldorado: representações da política em Londrina (1930-1975). 2 ed. Londrina: EDUEL, 2008.

BENATTE, Antonio Paulo. O centro e as margens: boemia e prostituição na capital "mundial do café" (Londrina: 1930-1970). 1996. Dissertação (Mestrado em História) -Universidade Federal do Paraná, Curitiba, 1996.

BITTENCOURT, Circe Maria Fernandes. Museu e seus objetos. In: BITTENCOURT, Circe Maria Fernandes. Ensino de História: Fundamentos e Métodos. São Paulo: Cortez, 2008, p. 354-360.

BRASIL. Lei n 11.904. Institui o Estatuto de Museus e dá outras providências. Brasília: Ministério da Cultura, 2009.

BRASIL. Ministério da Cultura. IPHAN. Departamento de Museus e Centro Culturais; MINAS GERAIS. Secretaria de Estado da Cultura. Superintendência de Museus. Caderno de diretrizes museológicas I. 1. ed. Belo Horizonte, 2006.

BRUNO, Maria Cristina Oliveira. Memorial Descritivo. Conceição Geraldo. São Paulo, 22 de junho de 1998. Carta impressa.

CHARTIER, Roger. Introdução. Por uma sociologia histórica das práticas culturais. In: CHARTIER, Roger. A História Cultural entre práticas e representações. (Coleção Memória e sociedade). Tradução de Maria Manuela Galhardo. Rio de Janeiro: Bertrand Brasil, 1990, p. 13-28.

CURY, Marília Xavier. Exposição: Análise metodológica de processo de concepção, montagem e avaliação. 1999. São Paulo: Dissertação de mestrado, ECA/USP, 1999.

DESVALLÉES, André. et al. Conceitos-chave de Museologia. Tradução de Bruno Brulon Soares e Marilia Xavier Cury. São Paulo: Comitê Brasileiro do Conselho Internacional de Museus, 2013.

FERNANDES, Aryane Kovacs. Narrativas de quem ensina: utilização de fotografias da exposição permanente do Museu Histórico de Londrina por monitores e professores (2014). 2014. Trabalho de Conclusão de Curso (Licenciatura em História) - Universidade Estadual de Londrina. Londrina, 2014. 
GINZBURG, Carlo. Distância e mentira. In: GINZBURG, Carlo. Olhos de madeira: nove reflexões sobre a distância. Tradução de Eduardo Brandão. São Paulo: Companhia das Letras, 2001, p. 42-84.

HALBWACHS, Maurice. A memória coletiva. São Paulo: Vertice, 1990.

HILDEBRANDO, Gilberto. O museu e a escola: memórias e histórias em uma cidade de formação recente - Londrina/PR. 2010. Dissertação (Mestrado em História Social) -Universidade Estadual de Londrina, Londrina, 2012.

JULIÃO, Letícia. Apontamentos sobre a história do Museu. In: NASCIMENTO, Silvania Sousa do. (Coord.). Caderno de Diretrizes Museológicas I. Belo Horizonte: Secretaria de Estado da Cultura/Superintendência de Museus, 2006a, p. 17-30.

JULIÃO, Letícia. Pesquisa Histórica no Museu. In: NASCIMENTO, Silvania Sousa do. (Coord.). Caderno de Diretrizes Museológicas I. Belo Horizonte: Secretaria de Estado da Cultura/Superintendência de Museus, 2006b, p. 91-107.

LEME, Edson José Holtz. O Teatro da Memória: o Museu Histórico de Londrina: 1959-2000. 2013. Tese (Doutorado em História) - Faculdade de Ciências e Letras, Universidade Estadual Paulista, Assis, 2013.

LE GOFF, Jacques. Documento/monumento. Enciclopédia Einaldi, v. 1, Lisboa: Imprensa Nacional/Casa da Moeda, 1984.

MARTINEZ, Cláudia Eliane P. Entre palavras e imagens: famílias negras no $\mathrm{Mu}-$ seu Histórico de Londrina/PR (1970-2016). Revista de História Regional, v. 23, n. 2 , p. 321-343. 2018.

MENESES, Ulpiano Toledo Bezerra de. A exposição museológica e o conhecimento histórico. In: FIGUEIREDO, Betânia Gonçalves; VIDAL, Diana Gonçalves (org.). Museus: dos gabinetes de curiosidades à museologia moderna. Belo Horizonte: Argvmentvm, 2005, p. 15-84.

MORAES, Roque. Uma tempestade de luz: a compreensão possibilitada pela análise textual discursiva. Ciência e Educação, v. 9, n. 2, p. 191-211. 2003.

NORA, Pierre. Entre Memória e História: a problemática dos lugares. Tradução de Yara Maria Aun Khoury. Projeto História, São Paulo, n. 10, p. 07-28. 1993.

POLLAK, Michael. Memória e Identidade Social. Estudos Históricos. Rio de Janeiro, v.5, n. 10, p. 200-212. 1992.

RAMOS, Francisco Régis Lopes. A danação do objeto: o museu no ensino de história. $1^{\text {a }}$ ed. Chapecó: Argos, 2004. 
SANTOS, Myrian Sepúlveda dos. A escrita do passado em museus históricos. Rio de Janeiro: Garamond, 2006.

SETI. Seminário destaca acervos de culturas indígenas, 2016. Disponível em: < http://www.seti.pr.gov.br/Noticia/Seminario-destaca-acervos-de-Culturas-indigenas>. Acesso em: 29 set. 2020.

SILVA, Taiane Vanessa da. A história de Londrina em foco: apropriações da narrativa do Museu Histórico de Londrina por professoras do ensino básico (19962015). 2016. Trabalho de Conclusão de Curso (Licenciatura em História) - Universidade Estadual de Londrina, Londrina, 2016.

SIMAN, Lana Mara de Castro. O papel dos mediadores culturais e da ação mediadora do professor no processo de construção do conhecimento histórico pelos alunos. In:

ZARTH, Paulo A. et al. (Orgs.). Ensino de História e Educação. Ijuí: Ed. UNIJUÍ, 2004, p. 81-107.

Recebido em: 01/10/2020

Aceito em: 05/07/2021 